Нина Љ. Судимац*

Универзитет у Нишу

Филозофски факултет

Департман за српски језик

https://doi.org/10.18485/ai_fonefonosj.2020.ch12

811.163.41'282'342.42

\title{
ТРАЈАЮЕ ВОКАЛА У ДВА РЕГИОНАЛНА ВАРИЈЕТЕТА СРПСКОГ ЈЕЗИКА
}

Савремена социофонетска истраживања базирана су на утврђивању сличности и разлика акустичких параметара у контексту друштвених фактора, као што су пол, узраст, образовање, регионална припадност итд. Као релевантни и главни параметри за описивање вокала у регионалним варијететима једног језика наводе се боја вокала (вредности вокалских формантних фреквенција) и трајање вокала. У овом раду представљени су резултати истраживања у коме је мерено трајање наглашених и ненаглашених вокала /a/, /e/, /i/, /o/ и /u/ у два регионална варијетета српског језика: крушевачком и леско-

* nina.sudimac@filfak.ni.ac.rs.

** Рад је урађен у оквиру пројекта Српски језик некад и сад: тингвистичка истраживаюа (бр. пројекта 360/1-16-1001) чији је носилац Филозофски факултет Универзитета у Нишу, као и у оквиру пројекта Говорни и стандардни језик у јавној комуникацији у Ниму (О-25-20) који се реализује у оквиру огранка САНУ у Нишу. Рад се заснива на једном делу података добијеним експерименталним истраживањем за потребе писања ауторове докторске дисертације под називом Акустички квалитет вокала у типично регионалним варијететима српског језика, пријављене на Филозофском факултете у Нишу и одобрене од стране Универзитета у Нишу (ментор доц. др Александра Лончар Раичевић). Подаци у вези са трајањем вокала коришћени су како би се испитао утицај вокалског квантитета на акустички квалитет вокала. 
вачком. Корпус за анализу представљале су двосложне речи у четири нормативно очекиване категорије без неакцентоване дужине (нпр. ка̀naк, ка̄na, ка̂nu, па́так). Подаци су добијени мерењем параметара трајања помоћу софтверског пакета за обраду говора (PRAAT, верзија 6.0.14, BOERSMA \& WEENICK 2016), а потом и обрађени квантитативним путем - SPSS (верзија 24.00). Резултати показују да се трајање наведених вокала манифестује различито у испитиваним варијететима и да може бити један од битних регионалних маркера.

Кључне речи: трајање, вокали, варијетети, српски језик, регионални маркер, социофонетика.

\section{1. Увод}

О трајању вокала вршена су различита истраживања у којима је показан утицај многобројних лингвистичких фактора (сегментних, силабичких, супрасилабичких) на временски интервал одређеног исказа. Са друге стране, многи нелингвистички, односно, социјални фактори могу утицати на трајање говорног сегмента, а то су: пол, узраст, образовање, друштвени и економски статус, религијиска и етничка припадност итд. Испитивањем регионалних и друштвених варијација у језику бави се социолингвистика која посматра однос језика и друштва, односно на који начин друштвене околности и промене утичу на језик као систем. Стратификација ${ }^{1}$ се може одвијати у више праваца и као таква остављати различите резултате за собом.

1 Термин стратификација уводи Лабов у свом пионирском раду из 1966. године - The social stratiffication of English in New York сіty. Стратификација, раслојаваюе, варијетети, вернакулари представљају синонимне облике за исту појаву. 
Регионална раслојеност ${ }^{2}$ одређене језичке територије доводи до стварања регионалних (територијалних) варијетета ${ }^{3}$ између којих постоје разлике како на лексичком тако и на плану граматике и изговора ${ }^{4}$. Проучавајући варијације у изговору, можемо пратити одређене елементе који се могу уочавати са становишта перцептивне (слушне) перспективе; варијације у језику можемо пратити и проучавањем реализације акустичких параметара, те је и то један од елемената које треба укључити приликом истраживања. Појава Лабова и његових социофонетских истраживања, у којима је главни циљ био испитивање варијација у изговору вокала и консонаната, изазвала је настанак низа радова у којима су мерени главни акустички параметри, пре свега формантне фреквенције вокала.

Трајање вокала, поред формантних фреквенција, може бити значајан показатељ и регионалне и социоекономске припадности сваког појединца, те је важно испитивати га у истраживањима оваквога типа. Социофонетски опис регионалних варијетета српског језика, коришћењем метода експерименталне фонетике, главни је темељ и основ овога рада. Основни циљ рада јесте да се кроз једно експериментално истраживање испита трајање наглашених и ненаглашених вокала /a/, /e/, /i/, /o/, /u/ у два варијетета српског језика: крушевачком и лесковачком.

2 О раслојености пише Радовановић, наводећи да постоји неколико типова раслојавања: функционално, територијално, индивидуално и социјално (1979: 73-76).

3 Разноликост је специфичан скуп језичких предмета или образаца људског говора које наизглед можемо повезати са неким спољним фактором, географским подручјем или друштвеном групом (Hudson 1996).

4 Најпознатији пример у науци односи се на постојање британског и америчког енглеског. 
Рад је организован на следећи начин: прво поглавље је уводног карактера; у другом поглављу приказана су претходна истраживања у вези са трајањем вокала у српском језику; треће поглавље описује методолошке поставке рада; у четвртом поглављу приказана је анализа добијених резултата, док пето поглавље доноси закључне напомене у вези са испитиваном појавом.

\section{2. Претходна истраживања}

Акустичка манифестација параметра трајања вокала широко је испитивана тема како у домаћој (ИвићЛехисте 1963, Јокановић-Михајлов 1983, Пауновић 2003, Совиљ-Никић 2007, 2010, Марковић-Бјелаковић 2009a, 2009б, Лончар Раичевић 2015, 2016а, 2016б, Средојевић 2017, Лончар Раичевић-Судимац 2017a, 2017б, 2018, 2019), тако и у страној литератури (Lehiste and Peterson 1961, Kent and Read 2002, Ladefoged 2007).

Године 1963. Ивић и Лехисте спровели су истраживање чији је циљ био „da se utvrdi fonetska priroda tzv. akcenata reči u savremenom srpskohrvatskom književnom jeziku" (1963: 31). С тим у вези мерено је трајање вокала српског језика код говорника који су већином са подручја Војводине.

Наредна истраживања такође су била базирана на испитивању трајања наглашених и ненаглашених вокала у говору испитаника који су са прогресивнијих штокавских говора: (а) у истраживањима Јокановић-Михајлов (1983: 298) испитаници су били пореклом из Шумадије, западне Србије, источне Херцеговине, северне Црне Горе, источне и западне Босне, Војводине и Београда; (б) у радовима Марковић и Бјелаковић (2009a, б) и Средојевић (2017) испитивана је акустичка реализација параметра трајања вокала код испитаника 
који су пореклом из Војводине, уже - из Новог Сада; (в) у раду под називом Прилог проучавану природе акцената у српском језику, Лончар Раичевић је дала описе акцената на примеру изговора говорника који су пореклом из Ужица.

Совиљ-Никић (2010) је у раду Трајағе гласова и бактори који га одређују у српском и другим језицима указала на утицај низа фактора лингвистичке природе ${ }^{5}$ на трајање гласова, што предстваља основу за „развој модела трајања гласова у синтези говора” (2010: 602). ${ }^{6}$

Подаци у вези са трајањем вокала на подручју призренско-тимочке средине дати су у радовима Пауновић (2003) и Лончар Раичевић и Судимац (2017а, б; 2018, 2019). Описујућиу трајање вокала код испитаника из Ниша, (а) Пауновић указује да на овим просторима постоје квантитативне опозиције између дугих, кратких и ненаглашених вокала и да су „kvantitativne razlike $\mathrm{u}$ niškom varijetetu značajno manje od onih tipičnih za standardni srpski jezik" (Paunović 2003: 513); (б) у низу радова у којима се описују прозодијске јединице на подручју призренско-тимочке средине, Лончар Раичевић и Судимац дају податке за трајање вокала на корпусу речи у четири нормативно очекиване акценатске категорије: испитиване су акустичке реализације нагласка у највећим центрима сва три дијалекта - у Нишу, Лесковцу, Врању, Сврљигу и Пироту.

Говор Лесковца сврставамо у говоре призренско-тимочкое зоне, уже - у говоре призренско-јужно-

5 О утицају финалног (звучног/безвучног) консонанта на трајање вокала погледати радове Совиљ Никић 2007, Соколовић 2010, Судимац 2017.

6 Ауторка издваја следеће факторе који имају директног утицаја на трајање одређеног исказа: тренутни сегмент (идентитет сегмента), непосредно окружење (претходни и наредни сегмент), положај сегмента у слогу, слог, положај слога у речи, реч, фокус, положај речи у фрази (Совиљ-Никић 2010: 605). 
моравског дијалекта, чије је најпотпуније описе дао Белић (1905: 89). Специфичност ових говора огледа се у постојању само једног акцента који по својој природи није својствен акцентима са штокавских простора: у питању је такозвани експираторни акценат и може се јавити у свим позицијама и слоговима акцентоване речи (Ресо 1985: 151). О природи експираторног акцента аутори су забележили да је динамичког карактера - присутан је само удар, без икаквих квантитативних и тонских карактеристика (Белић 1905: 271; Ивић 1985: 112). Сва наведена истраживања базирала су се на методама слушне перцепције, док су први налази експерименталног карактера дати у раду Акустички опис нагласка у говорима призренско-јужноморавског дијалекта (Лончар Раичевић и Судимац 2017а): „Просечни квантитет наглашених вокала износи око $101 \mathrm{~ms}$ (просечно трајање вокала под дугим акцентима износи 106 ms, а под кратким 97 ms), док просечно трајање ненаглашеног вокала износи $52 \mathrm{~ms}$ (просечно трајање ненаглашених вокала и у речима са дугим и у речима са кратким наглашеним вокалима износи $51 \mathrm{~ms})$." (Лончар Раичевић и Судимац 2017a: 217).

Говор Крушевца припада староштокавској групи говора косовско-ресавске зоне који се у литератури описују као говори са два (три акцента): „novija ispitivanja [...] pokazala su da kosovsko-resavska zona, u stvari, ima troakcenatsku, a ponegde čak i četvoroakcenatsku sistemu: pored dva silazna javlja se i dugouzlazni akcenat" (Peco 1985: 142); ови говори познају и предакценатску дужину и некацентовану краткоћу (Јовић 1968: 38). Пецо напомиње да овим говорима није непознат ни краткоузлазни акценат, али да се јавља спорадично, те наводи неколико забележених примера у говору Трстеника и Левча. Занимљиво је да Јовић даје описе о природи акцената на овим просторима, ослањајући се на метод слушне пер- 
цепције, те бележи да су: „дужина и тон интензивнији [...] него у књижевном језику. Дуги акценти одлично се распознају и у динамичној говорној ситуацији. [...] Изразитост дугих вокала под акцентом ствара врло велику разлику у артикулацији акцентованог и следећег слога." (Јовић 1968: 42). Сви описи у вези са трајањем вокала у говорима косовско-ресавског дијалекта дата су у дијалектолошкој литератури, док експериментална истраживања нису вршена на овим просторима.

У овоме раду изнећемо део резултата о трајању наглашених и ненаглашених вокала у два регионална варијетета српског језика - крушевачком и лесковачком, које је мерено у истим експерименталним и методолошким условима. Како је претходно истраживање (Судимац 2019) показало да постоји веза између акустичког параметра трајања вокала (у спонтаном говору, на примеру три вокала /a/, /i/, /u/) и ставова испитаника према проучаваним варијететима, било је природно наставити са истраживањима оваквог типа на примеру свих пет вокала и у другачијим методолошким условима. Допринос рада огледа се првенствено у опису трајања вокала, базираном на методама експерименталне фонетике, у говору Крушевца; такође, рад доноси одговор на питање - да ли постоје дијалекатске разлике у трајању наглашених и ненглашених вокала и какве су, када се спроведу истоветна експериментална истраживања у одабраним варијететима.

\section{3. Методологија}

3.1. Истраживачка питања.

Иницијално дефинисана питања на која смо желели да добијемо одговоре била су: 
1. Који од пет испитиваних вокала у наглашеној и ненаглашеној позицији траје најдуже, а који најкраће, у продукцији испитаника сваког појединачно испитиваног варијетета?

2. Какав је утицај прозодисјких једница на трајање вокала?

3. Какав је однос у трајању фонолошки дугих и фонолошки кратких вокала код испитаника у два варијетета?

4. Какав је однос у квантитетским дистинкцијам између наглашених и ненаглашених вокала?

5. Да ли постоји статистички значајна разлика у реализацији трајања вокала код испитаника из Крушевца и Лесковца?

\section{2. Говорници}

У раду су представљени резултати изговорени од стране 20 говорника - 10 по одабраном варијетету, женског пола. Испитаници су бирани на основу (а) регионалног порекла - они који су рођени и одрасли у испитиваним градовима (Крушевцу, Лесковцу) и нису мењали место становања; (б) узраста - бирани су субјекти који су имали у распону од 40 до 50 година јер је тада најстабилнија артикулациона база; (в) образовања - средњошколско образовање; (г) пола ${ }^{7}$. Приликом одабира варијетета водили смо рачуна да буду заступљени највећи урбани центри једног регионалног подручја.

\section{3. Стимулуси}

Материјал коришћен у експерименталним истраживањима састојао се из 64 речи смештене у неутрални

7 За потребе истраживања докторске дисертације у сваком испитиваном варијетету експерименталном истраживању подвргнути су испитаници оба пола, али ће у овом раду, због методолошке уједначености и циља рада, бити приказани резултати који се односе само на један пол. 
реченични контекст. Одабране речи заузимале су медијалну реченичну позицију. Свих 5 вокала налазили су се у два консонантска окружења (а) фрикативном су̀сам, иуйла, суิша, су́сед и (б) плозивном - ду̀зме, кӥга, бубағ, ту́zа. Као лингвистички фактори укључени су и (a) супрасегментални елементи (узети су примери код којих се нормативно очекују сва четири акцента и примери који су потврђени у Речнику Матице српске, 2011), (б) број слогова - двосложне речи (в) наглашеност вокала - проучавано је трајање вокала и у наглашеној и у ненаглашеној позицији; (г) важан фактор приликом дефинисања корпуса, који је битно утицао на одабир примера и сужавање могућности флексибилнијег одабира, био је следећи: одабрати примере двосложних речи код којих су нормативно очекиване све четири прозодеме, које се налазе у плозивном и фрикативном окружењу (због коартикулације) и код којих је место акцента исто у свим испитиваним варијететима како би методолошки услови били истоветни. Сви испитаници снимани су под истим условима, у тихим просторијама где је елиминисан било који траг буке. Снимање је вршено уз помоћ микрофона ATH-750COM (од ког су испитаници били удаљени десетак центиметара) директно у PRAAT-у (верзија 6.0.14, BOERSMA \& WEENICK 2016), програму који је и коришћен за акустичку анализу снимака. Испитаницима је дато упутство да све реченице читају неутралном реченичном интонацијом, природном говорном брзином, јер је познато да већа брзина утиче на скраћивање трајања вокала и слабије промене вокалских форманата.

\section{4. Статистичка обрада података}

Добијени подаци обрађени су квантитативним путем (SPSS, верзија 24.00). Статистичка анализа обухва- 
тала је дескриптивну статистику где је израчуната просечна вредност трајања вокала, $f$ статистика (користи се у рачунању значајности) и стандардна девијација. Нормалност расподеле података је проверена тестом Колмогоров Смирнова. С обзиром на то да су све значајности веће од 0.05, може се закључити да су подаци у свим групама расподељени по нормалном закону расподеле. Због тога смо се приликом поређења добијених резултата користили параметарским тестовима - у овом случају АНОВА. Подаци су представљени таблеарним путем и пропраћени су графиконима (Microsoft Office Excel 2016).

\section{4. Анализа резултата}

4.1. Трајање вокала у наглашеном слогу

у два варијетета српског језика

Табела 1: Трајағе наглашених вокала у два регионална варијетета српског језика изражено у милисекундама

$\begin{array}{cccccc}\text { Варијетет } & \text { Вокал } & \text { Mean } & \text { SD } & \text { F } & \text { sig } \\ & \text { /a/ } & 149.50 & 28.45 & & \\ \text { /e/ } & 137.76 & 24.09 & & \\ \text { Крушевац } & \text { /i/ } & 108.82 & 27.38 & 19.651 & \mathbf{0 . 0 0 0} \\ & \text { /o/ } & 134.49 & 22.61 & & \\ \text { /u/ } & 108.52 & 27.87 & & \\ \text { Лесковац } & \text { /a/ } & 94.80 & 25.44 & & \\ & \text { /e/ } & 97.24 & 26.08 & & \\ & \text { /o/ } & 75.22 & 17.68 & 29.735 & \mathbf{0 . 0 0 0} \\ & \text { /u/ } & 97.11 & 25.29 & & \\ & 75.96 & 17.25 & & \end{array}$


У Табели 1 налазе се просечне вредности за трајање сваког појединачно испитиваног вокала, у оба варијетета: најдуже трајање код испитаника из Крушевца забележено је код вокала /a/ и износи 149,5 ms, а најкраће код високог вокала /u/ и износи 108,52 ms; најдуже трајање код испитаника из Лесковца забележено је код вокала /e/ и износи 97,24 ms, а најкраће такође код вокала високог реда /i/ и износи 75,22 ms. Приложене вредности сведоче о дужем трајању сваког поједичано испитиваног вокала код испитаника из Крушевца: разлика у трајању износи у просеку око $39,15^{8} \mathrm{~ms}$. Резултати показују да постоји статистичка значајности (р .000) између акустичког параметра трајања и врсте вокала.

Резултати двофакторске анализе (АНОВА, табела у Прилогу број 1) показују да постоји значајна разлика у реализацији акустичког параметра трајања и у односу на варијетет (р .000) и у односу на појединачно испитивани вокал (р .000). Такође, постоји и значајан утицај интеракције ових двају фактора (р .001), а то се огледа у чињеници да су различите скале по дужини: распоред трајања наглашених вокала у крушевачком варијетету je /a, e, o, i, u/ док је у лесковачком варијетету поредак /e, o, a, u, i/.

\section{2. Утицај супрасегментних јединица на трајање наглашених вокала у два варијетета српског језика}

8 Ако узмемо податак да просечно трајање вокала у крушевачком варијетету износи $127,21 \mathrm{~ms}$, а у лесковачком $88,06 \mathrm{~ms}$. 

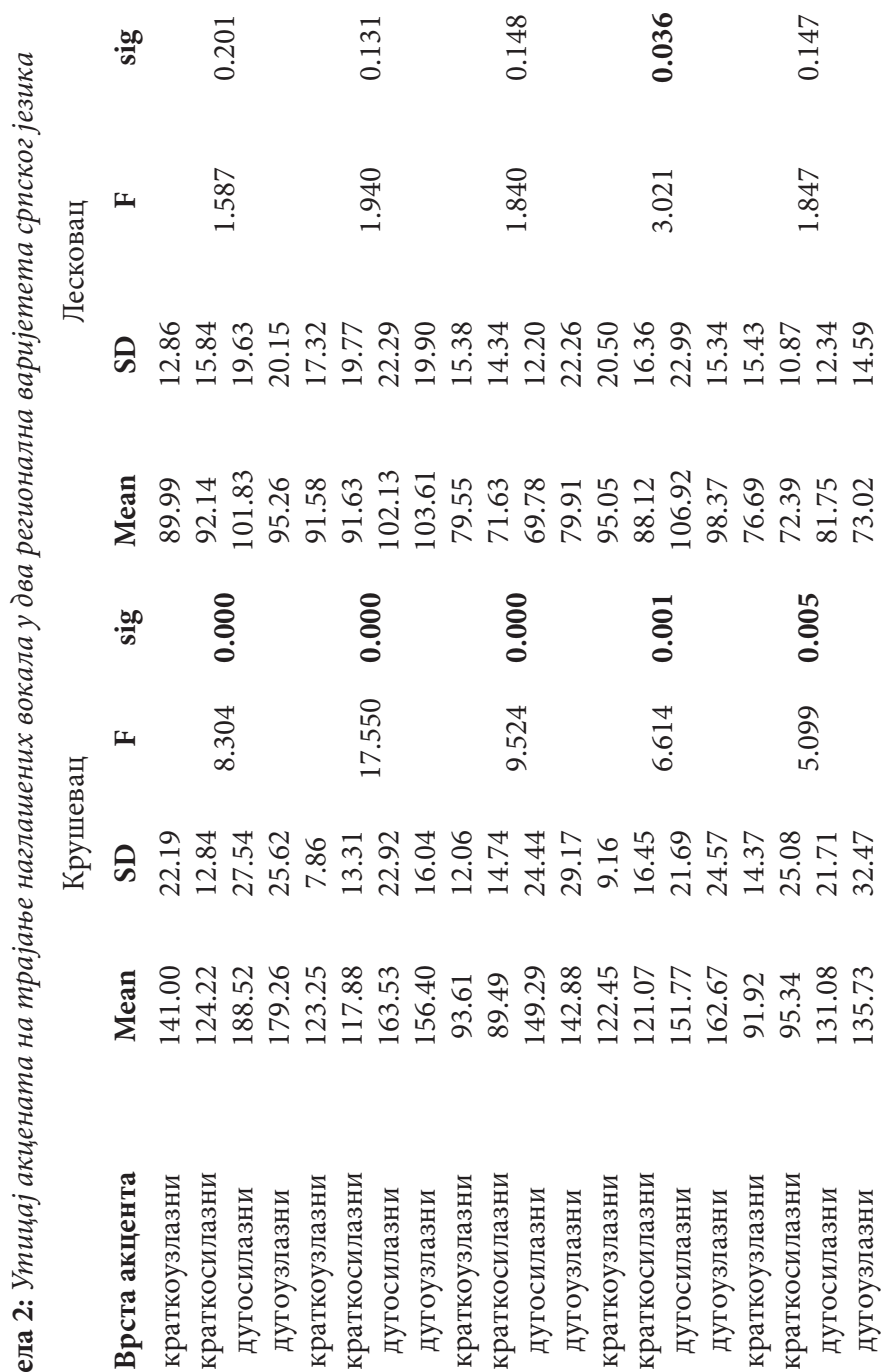

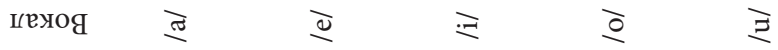


На основу података у Табели 2 уочава се да је код испитаника из Крушевца најкраће трајање забележено код вокала под нормативно очекиваним краткосилазним акцентима, осим код вокала /u/ где је најкраће трајање забележено под нормативно очекиваним краткоузлазним акцентом; најдуже трајање забележено је код дугих акцената и то - код вокала /a/ и /e/ под нормативно очекиваним дугосилазним акцентом, а код вокала /i/, /o/ и /u/ под нормативно очекиваним дугоузлазним акцентом; најкраће трајање у наглашеној позицији забележено је код ниских вокала /i/ и /u/. Средња вредност разлике у трајању вокала под нормативно очекиваним дугоузлазним и дугосилазним акцентом варира у односу на испитивани вокал: код вокала /a/ износи 9,26 ms, код вокала /e/ 7,13 ms, код вокала /i/ износи $6,41 \mathrm{~ms}$, код /o/ 10,9 ms, код вокала /u/ износи 4,65 ms; разлика у трајању вокала под нормативно очекиваним краткоузалзним и краткосилазним акцентом, такође, варира у односу на испитивани вокал: код вокала /a/ износи $16,78 \mathrm{~ms}$, код вокала /е/ износи 5,37 ms, код вокала /i/ износи 4,12 ms, код /o/ 1,38 ms, а код вокала /u/ 3,42 ms. Резултати показују да код испитаника из Крушевца постоји статистичка значајност између трајања вокала и супрасегменталних елемената, код свих пет вокала у све четири нормативно очекиване категорије.

Код испитаника у Лесковцу резултати су другачији: најкраће трајање забележено је под нормативно очекиваним краткузлазним акцентом и то код вокала /a/ и /e/, затим под под нормативно очекиваним краткосилазним акцентом код вокала /o/ и /u/, док је код вокала /i/ најкраће трајање забележено под нормативно очекиваним дугосилазним акцентом; најдуже трајање забележено је код дугих акцената и то - код вокала /a/, /o/ и /u/ под нормативно очекиваним дугосилазним 
акцентом, а код вокала /e/ и /i/ под нормативно очекиваним дугоузлазним акцентом. Средња вредност разлике у трајању вокала под нормативно очекиваним дугоузлазним и дугосилазним акцентом варира у односу на испитивани вокал: код вокала /a/ износи 6,57 ms, код вокала /е/ износи 13,59 ms, код /o/ 8,55 $\mathrm{ms}$, код вокала /u/ износи $8,73 \mathrm{~ms}$; разлика у трајању вокала под нормативно очекиваним краткоузалзним и краткосилазним акцентом, такође, варира у односу на испитивани вокал: код вокала /a/ износи 2,15 ms, док код вокала /e/ износи 0,05 ms, код вокала /i/ износи 4,12 $\mathrm{ms}$, код /o/ 6,93 ms, а код вокала /u/ 4,3 ms. Резултати показују да не постоји статистичка значајност између трајања вокала и нормативно очекиваних прозодијских јединица, осим код вокала /o/ (р .0036).

Слика 1: Графички приказ трајата наглачених вокала у два регионална варијетета српског језика ${ }^{9}$

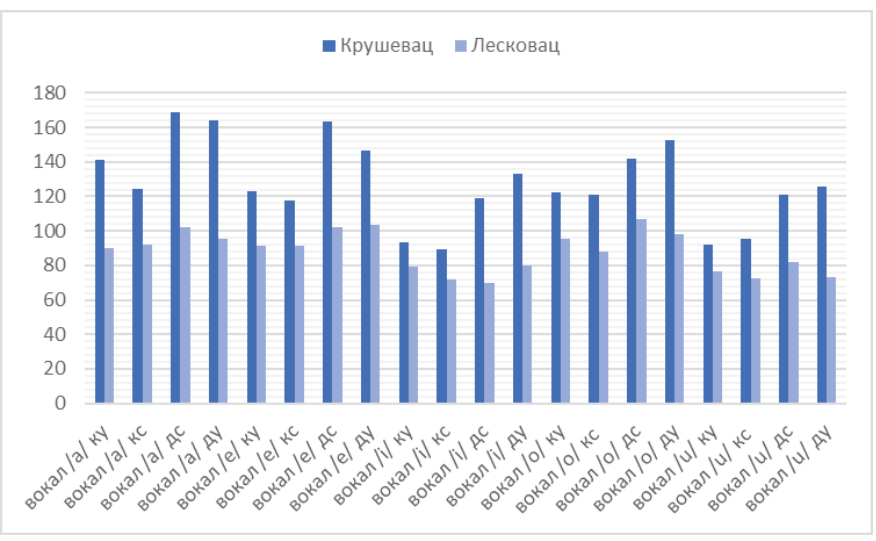

9 У доњем делу графичког приказа налазе се следеће скраћенице: КУ - краткоузлазни акценат, КС - краткосилазни акценат, ДС дугосилазни акценат, ДУ - дугоузлазни акценат. 
4.3. Квантитетске дистинкције између наглашених вокала у два регионална варијетета српског језика

У наредној табели налазе се подаци везани за однос трајања фонолошки дугих и фонолошки кратких вокала код испитаника из Крушевца и Лесковца.

Табела 3: Трајане фонолошки дугих и кратких вокала у регионалним варијететима српског језика

$\begin{array}{cccccc}\text { Варијетет } & \begin{array}{c}\text { Дуги/кратки } \\ \text { акценти }\end{array} & \text { Mean } & \text { SD } & \text { F } & \text { sig } \\ \text { Крушевац } & \text { дуги } & 173.61 & 29.63 & & \\ \text { кратки } & 112.02 & 22.64 & 71.773 & 0.000 \\ \text { Лесковац } & \text { дуги } & 91.26 & 22.36 & & \\ & \text { кратки } & 84.88 & 17.82 & 8.963 & 0.003\end{array}$

Апсолутне вредности показују да је просечно трајање фонолошки дугог акцента код испитаника у Крушевцу 173,61 ms, а у Лесковцу 91,26 ms: квантитативна разлика износи 82,35 ms, тј. реалтивна вредност указује да је однос трајања дугих вокала у ова два варијетета 17 : 9 (фонолошки дуг наглашени вокал траје скоро дупло дуже код испитаника у Крушевцу у односу на испитанике у Лесковцу - однос је 1,9: 1). Просечно трајање фонолошки кратког вокала код испитаника из Крушевца износи 112,02 ms, а код испитаника из Лесковца износи 84,88 ms: кванитативна разлика 27,14 $\mathrm{ms}$, тj. релативна вредност указује да је однос трајања кратких вокала у ова два варијетета 11 : 8. Већа квантитативна разлика међу фонолошки дугим вокалима очекивана је с обзиром на изразито дуго трајање дугих вокала код испитаника из Крушевца.

Са друге стране, квантитативна разлика између фонолошки дугих и фонолошки кратких вокала код 
испитаника из Крушевца износи 61,59 ms, а код испитаника из Лесковца 6,38 ms: однос између фонолошки дугих и кратких вокала код испитаника из Крушевца износи $17: 11$, а из Лесковца $9: 8$.

Резултати двофакторске анализе показују да постоји значајна разлика (р .000) у трајању вокала у односу на опозицију фонолшки дуг : фонолошки кратак вокал и у односу на варијетет из кога су испитаници: значајна интеракција ових двају фактора се рефлектује у много већој разлици у трајању у Крушевцу него у Лесковцу.

Табела 4: Поређење трајаға вокала двосложних речи са силазним и узлазним акиентима у два регионална варијетета српског језика

\begin{tabular}{ccccccc} 
Варијетет & Акценат & Mean & SD & F & sig \\
& & & & & & \\
Крушевац & узлазни & кратки & 114.44 & 23.38 & 32.746 & $\mathbf{. 0 0 0}$ \\
& & дуги & 151,38 & 28.67 & & \\
& силазни & кратки & 109.60 & 21.83 & 38.707 & $\mathbf{. 0 0 0}$ \\
& & дуги & 160.83 & 30.83 & & \\
Лесковац & узлазни & кратки & 93.24 & 21.44 & .620 & .433 \\
& & дуги & 97.28 & 24.38 & & \\
& \multirow{2}{*}{ силазни } & кратки & 88.95 & 22.50 & 2.338 & .130 \\
& & дуги & 97.60 & 27.83 & &
\end{tabular}

На крају, резултати кванитативне анализе (подаци приказани у Табели 4) показују до постоји статистичка значајност у трајању фонолошки дугих и кратких вокала када је наглашени вокал и под нормативно очекиваним узлазним и силазним акцентом (р .000) код испитаника из Крушевца, док статистичка значајност у трајању фонолшки дугих и кратких вокала у двема нормативно очекиваним категоријама не постоји код испитаника из Лесковца. 
4.4. Трајање ненаглашених вокала

у два регионална варијетета српског језика

Табела 5: Разлика између два регионална варијетета српског језика у трајаюу ненаглашених вокала

$\begin{array}{ccccccc}\text { Вокал } & \text { Варијетет } & \mathrm{N} & \text { Mean } & \text { StD } & \text { F } & \text { sig } \\ & \text { Крушевац } & 20 & 68.35 & 11.65 & & \\ \text { /a/ } & \text { Лесковац } & 20 & 54.07 & 24.06 & .669 & \mathbf{. 0 1 8} \\ & \text { Крушевац } & 20 & 67.24 & 10.16 & & \\ \text { /e/ } & \text { Лесковац } & 20 & 53.35 & 14.69 & 4.898 & \mathbf{. 0 3 0} \\ & \text { Крушевац } & 20 & 69.38 & 11.09 & & \\ \text { /i/ } & \text { Лесковац } & 20 & 54.74 & 14.79 & 6.949 & \mathbf{. 0 1 0} \\ & \text { Крушевац } & 20 & 74.86 & 12.17 & & \\ \text { /o/ } & \text { Лесковац } & 20 & 55.16 & 19.54 & 4.139 & \mathbf{. 0 4 7} \\ & \text { Крушевац } & 20 & 68.55 & 9.16 & & \\ \text { /u/ } & \text { Лесковац } & 20 & 52.26 & 15.02 & 12.137 & \mathbf{. 0 0 1} \\ & & & & & & \end{array}$

Најдуже трајање вокала у ненаглашеној позицији забележено је код вокала /о/ код испитаника из Крушевца и износи 74,86 ms, као и код испитаника из Лесковца - 55,16 ms; најкраће трајање вокала /е/ забележеноје код испитаника из Крушевца (износи 67,24 ms), а код испитаника из Лесковца најкраће трајање забележено је код вокала /u/ и износи 52,26 ms. Квантитативна разлика код вокала који имају најдуже трајање у испитиваним варијететима износи $19,7 \mathrm{~ms}$, а код вокала који имају најкраће трајање износи 14,98 ms.

Квантитативна разлика у трајању ненаглашеног вокала /a/ износи 14,28 ms, код вокала /e/ 13,89 ms, код вокала /i/ 14,64 ms, код вокала /o/ 19,7 ms, а код вокала /u/ 16,29 ms. На основу добијених података можемо направити градациони поредак у трајању вокала у ненаглашено позицији -од оних који трају најдуже, до оних који најкраће трају: поредак у продукцији испитаника из Крушевца је /o, i, u, a, e/, а код испитаника из Лесков- 
ца /o, i, a, e, u/.

Резултати статичке анализе добијених вредности показују да је разлика у трајању ненаглашених вокала код испитаника из два варијетета статистички значајна код свих вокала.

Слика 2: Графички приказ трајања наглашених вокала у два регионална варијетета српског језика

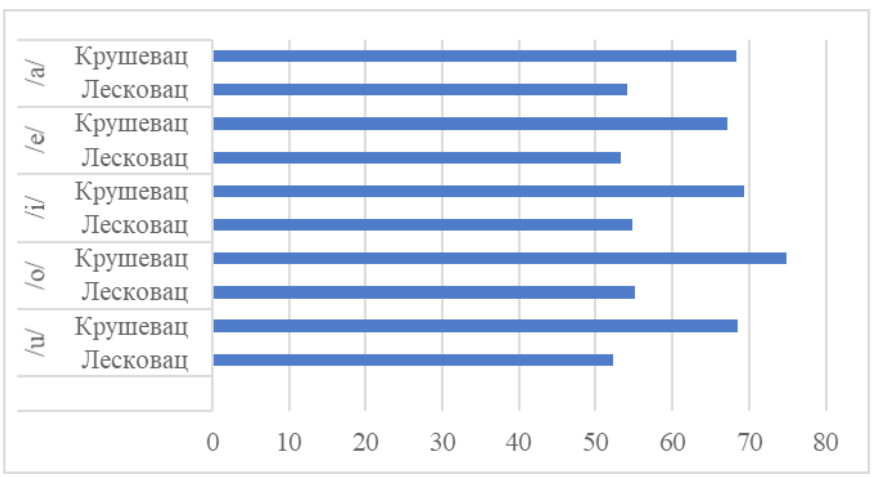

4.5. Квантитетске дистинкције између наглашених и ненаглашених вокала у два регионална варијетета српског језика 


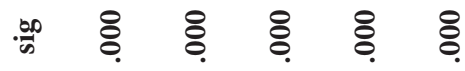

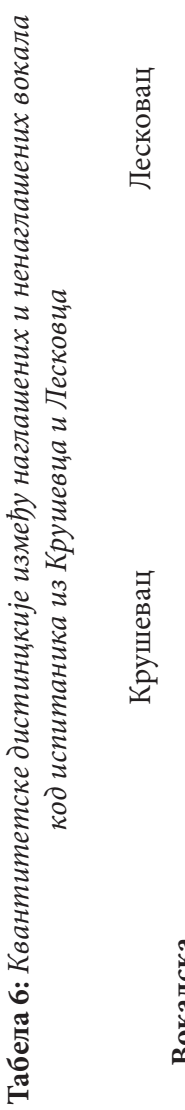

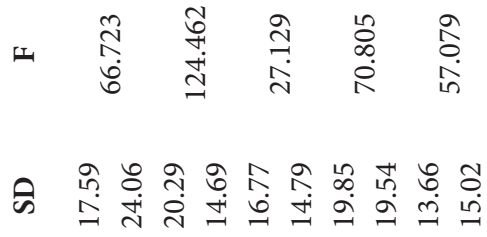

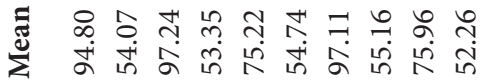

के छे के छे

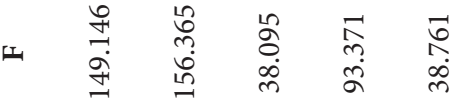

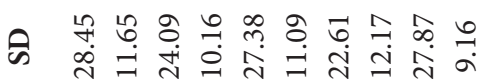

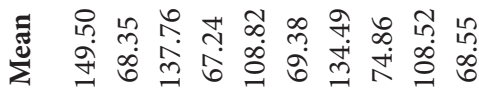

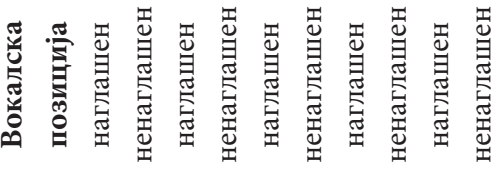

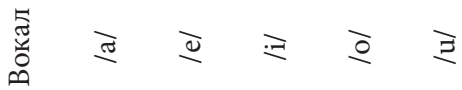


Анализа добијених примера указује на доследно дуже трајање вокала у наглашеној позицији у односу на вокал у ненаглашеној позицији. И код испитаника из Крушевца и код испитаника из Лесковца забележено је дуже трајање свих пет наглашених вокала: код испитаника из Крушевца квантитетска дистикција између наглашеног и ненаглашеног вокала /a/ износи $81,15 \mathrm{~ms}$; код вокала /e/ 70,52 ms; код вокала /i/ 39,44; код вокала /о/ износи 59,63, а код вокала /u/ 39,9; код испитаника из Лесковца квантитетска разлика у трајању вокала /a/ износи 40,73 ms; код вокала /e/ 43,89 ms; код вокала /i/ 20,48 ms; код вокала /о / износи 41,95 ms, а код вокала /u/ 23,37 ms. Све разлике су статистички изузетно значајне. Подаци дати у Табели 6, као и израчунате квантитативне дистинкције, указују да је разлика у трајању наглашених и ненаглашених вокала већа код испитаника из Крушевца где је наглашени вокала два пута дужи од ненаглашеног - пре свега код вокала /a/ где је однос 2,18: 1 и код вокала /е/ где је однос 2,05: 1 . Квантитетске дистинкције између наглашених и ненаглашених вокала код испитаника из Лесковца су мање, с обзиром на краће трајање и наглашених и ненаглашених вокала: највећа разлика забележена је код вокала /e/ где је однос у трајању вокала $1,82: 1$.

\section{5. Закључак}

На основу анализе добијених вредности можемо извести одређене закључке у вези са трајањем вокала:

1) отворени (високи) наглашени вокали имају дуже трајање него затворени (ниски) вокали код говорника из Крушевца и Лесковца: најдуже трајање забележено је код вокала /a/ код говорника у Крушевцу, док је код говорника у Лесковцу најдуже трајење забележено код 
вокала /e/; вокали /i/ и /u/ трају најкраће у оба испитивана варијетета;

2) прозодијски елементи код говорника из Крушевца играју значајну улогу у реализацији акустичког параметра трајања наглашеног вокала, што се показало и статистички значајно, док код говорника из Лесковца прозодијске јединице нису играле битну улогу, осим код вокала /u/;

3) отворен вокал /о/ има најдуже трајање у ненаглашеној позицији код обе групе говорника.

На основу анализе укупних података резултати јасно указују на чињеницу да код испитаника из Лесковца не постоји изражена разлика (6,38 ms) у трајању фонолошки дугих и кратких вокала. Међутим, код говорника из Крушевца јасно се уочава дуже трајање и наглашених и ненаглашених вокала тако да су резултати овог истраживања на својеврстан начин потврдили перцепцијске представе о дугом трајању вокала у косовско-ресавској зони, посебно у Крушевцу. Даља истраживања овог варијетета обухватиће и поређење са вредностима о реализацији трајања вокала у стандардном српском језику чиме ће описи бити употпуњени.

Приложени резултати указују да разлике у трајању наглашених и ненаглашених вокала постоје код испитаника двају регионалних варијетета српског језика и да се могу успешно користити као акустички маркери регионалног типа.

\section{ЛИТЕРАТУРА}

Белић 1905: А. Белић. Дијалекти источне и јужне Србије, Српски дијалектолошки зборник I, Београд: Српска краљевска академија наука. 
Боерсма и Виник 2016: P. Boersma \& David WeEnick. Praat: Doing Phonetics by Computer (Version6.0.14) [Computer program]. http://www.praat.org. 2. 5. 2016.

Ивић 1985: П. Ивић. Дијалектологија српскохрватског језика: Увод и штокавско наречје. Друго издање. Нови Сад: Матица српска.

Ивић и Лехисте 1963: P. Ivić i Ilse Lehiste. Prilozi ispitivanju fonetske $\mathrm{i}$ fonološke prirode akcenata $\mathrm{u}$ savremenom srpskohrvatskom književnom jeziku. Зборник Матице српске за филологију и лингвистику. Нови Сад. 6: 31-73. Јовић 1968: Д. Јовић. Трстенички говор. Српски дијалектолошки зборник XVII. Београд: 1-234.

Јокановићн-Михајлов 1983: Ј. Јокановић Михајлов. Природа узлазних акцената у прогресивнијим штокавским говорима. Српски дијалектолошки зборник, XIX, стр. 295-337.

Кент и Рид 2002: R. Kent \& Charles Read. Acoustic Analysis of Speech. $2^{\text {nd }}$ edition. San Diego: Singular Publish Group. Лабов 1966: W. Labov. The social stratification of English in New York City. Washington, DC, Center for Applied Linguistics. Ладефогед 2007: P. Ladefoged Phonetic Data Analysis. $4^{\text {th }}$ edition. Oxford: Blackwell Publishing.

Лехисте и Петерсон 1961: I. Lehiste \& Gordon Peterson. Some Basic Considerations in the Analysis of Intonation. Journal of the Acoustical Society of America 33, 419-425.

Лончар Раичевић 2015: A. Lončar Raičević. Acoustic Analysis of Post-accentual Quantitiy in Serbian. Facta Univeristatis, Series: Linguistic and Literature 13/2, 135-145.

Лончар Раичевић 2016а: А. Лончар Раичевић. Прозодија речи у говору ужичког краја. Бања Лука: Филолошки факултет [докторска дисертација].

Лончар Раичевић 2016б: А. Лончар Раичевић. Прилог проучавању природе акцената у српском језику. Српски језик XXI, 627-639.

Лончар Раичевић и Судимац 2017а: А. Лончар Раичевић и Нина Судимац. Акустички опис нагласка у говорима призренско-јужноморавског дијалекта, Зборник Матиие српске за филологију и лингвистику LX/2, Нови Сад, 209-225. 
Лончар Раичевић и Судимац 2017б: A. Loncar Raicevic i Nina Sudimac. Acoustic parameters of speech as forensic markers for speakers of Prizren-Timok ialect, Tematic conference proceedings of international significance Archibald Reiss Days, Tom I, Volume I, Academy of Criminalistic and Police Studies, Belgrade.

Лончар Раичевић и Судимац 2018: А. Лончар Раичевић и Нина Судимац. Акустички опис нагласка у говорима тимочко-лужничког дијалекта. Philologia Mediana, X/10. Ниш: Филозоски факултет, Универзитет у Нишу, 423-439.

Лончар Раичевић и Судимац 2019: А. Лончар Раичевић и Нина Судимац. Белићеви погледи на природу експираторног акцента из данашње перспективе. Philologia Mediana, XI/11. Ниш: Филозофски факултет Универзитета у Нишу, 203-215.

Марковић и Бјелаковић 2009а: М. Марковић и Исидора Бјелаковић. Квантитет дугих посттоничних вокала у говору Новог Сада. Жарко Бошњаковић (ур.). Говор Новог Сада, Св. 1, Фонетске особине. Нови Сад: Филозофски факултет Универзитета у Нишу, 141-147.

Марковић и Бјелаковић 2009б: М. Марковић и Исидора Бјелаковић. Квантитет наглашених вокала у говору Новог Сада. Жарко Бошњаковић (ур.). Говор Новог Сада, Св. 1, Фонетске особине. Нови Сад: Филозофски факултет Универзитета у Нишу, 148-158.

Пауновић 2003: T. Paunović. Fonetsko-fonološka interferencija srpskog jezika u percepciji i produkciji engleskih vokala. Doktorska disertacija. Filozofski fakultet, Univerzitet u Nišu.

Пецо 1985: А. Peco. Osnovi akcentologije srpskohrvatskog jezika. Beograd: Naučna knjiga.

Радовановић 2003: M. Radovanović. Sociolingvistika. Sremski Karlovci-Novi Sad: Izdavačka knjižarnica Zorana Stojanovića. Совиљ-Никић 2007: S. Sovilj Nikić. Trajanje vokala kao jedan od prozodijskih elemenata u sintezi govora na srpskom jeziku. Novi Sad: Fakultet tehničkih nauka. [rukopis magistarskog rada].

Совиљ-Никић 2010: S. Sovilj Nikić. Trajanje glasova i faktori koji ga određuju u srpskom i drugim jezicima. 18. 
Telekomunikacioni forum TELFOR 2010 Srbija, Beograd, novembar 23-25, 602-605.

Соколовић 2010: М. Соколовић. Трајање вокала као обележје контраста по звучности у српском језику. Годишњак за српски језик и књижевност, XXIII/10. Ниш: филозофски факултет у Нишу, 2010: 423-437.

Средојевић 2017: D. Sredojević. Fonetsko-fonološki opis akcenata u standardnom srpskom jeziku od specifičnog ka opštem. Novi Sad: Filozofski fakultet Univerziteta u Novom Sadu.

Судимац 2017: Н. Судимац. Скраћење вокалског трајања у српском и енглеском језику - контрастивно истраживање. Philologia Mediana, IX/9. Ниш: Филозоски факултет, Универзитет у Нишу, 501-528.

Судимац 2019: Н. Судимац. Вокалски квантитет у светлу ставова према варијететима српског језика. Октоих: Чaсопис Одјељења за српски језик и књижевност Матице српске - Друштвва чланова у Црној Гори IX/10, 37-53.

Хадсон 1996: R. A. Hudson. Sociolinguistics. Cambridge: Cambridge University Press.

Nina Lj. Sudimac

\section{VOWEL DURATION IN TWO REGIONAL VARIETES OF THE SERBIAN LANGUAGE}

\section{Summary}

Contemporary sociophonetic research is based on determining similarities and differences among acoustic parameters in the context of the following social factors: gender, age, education, regional affiliation, etc. The relevant and main parameters for describing the vowels of the regional variants of a language are vowel quality (vowel formant frequency values) and vowel duration. This paper presents the results of a research which examined the duration of stressed and unstressed vowels 
/a/, /e/ /i/, /o/, /u/ in two regional varietes of Serbian: Kruševac and Leskovac. The corpus included disyllabic words in four normatively expected categories with no unstressed length (e.g.

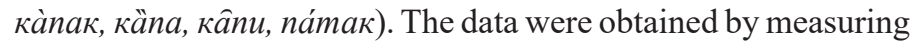
the duration parameters with the help of the speech processing software package (PRAAT, version 6.0.14, BOERSMA \& VEENICK 2016), and they were also processed quantitatively SPSS (version 24.00). The results showed that the duration of the investigated vowels was different in the given varieties and that it could represent an important regional marker.

Key words: duration, vowels, varietes, Serbian, regional marker, sociophonetics.

\section{Прилози}

Прилог број 1: Статистички подаци у вези са трајањем вокала и варијететима

$\begin{array}{ccccc}\text { Варијабле } & \mathrm{df} & \text { Mean Square } & \mathrm{F} & \text { sig } \\ \text { град } & 1 & 203160.04 & 454.113 & .000 \\ \text { вокал } & 4 & 21991.73 & 49.157 & .000 \\ \text { град * вокал } & 4 & 2051.62 & 4.586 & .001\end{array}$

